\title{
Multivariations of the Left Gastric Artery: A Case Report
}

\author{
Arteria Gastrica Sinistra'nın Çoklu Varyasyonları: Bir Olou Sunumu \\ Özcan GAYRETL $\dot{I}^{1}$, Necdet KOCABIYIK², Ayşin Çetiner KALE ${ }^{1}$, Bülent YALÇIN ${ }^{2}$, Hasan OZAN² \\ ${ }^{1}$ İstanbul Üniversitesi İstanbul Tip Fakültesi, Anatomi Anabilim Dall, İstanbul \\ ${ }^{2}$ Gülhane Askeri Tip Akademisi, Anatomi Anabilim Dall, Ankara
}

Submitted / Başvuru tarihi: 17.11.2008 Accepted / Kabul tarihi: 24.12.2008

The left gastric artery, which is the smallest branch of the coeliac trunk, travels along the lesser curvature of the stomach. During routine abdominal dissections, we encountered multivariations of the left gastric artery in a 65 year old male cadaver. The left gastric artery arose from the coeliac trunk as the first branch, afterwards it divided into two branches. The branch which passed to the right side gave three branches; to the left lobe of the liver (an accessory hepatic artery), to the fundus of the stomach and oesophagus, respectively. The branch which passed to the left side divided into two main trunks. The anterior trunk supplied the fundus and anterior wall of the stomach and the posterior trunk supplied the fundus and the posterior wall of the stomach. Consequently the posterior wall of the stomach was supplied by the posterior trunk instead of the posterior gastric artery of the splenic artery. Knowledge of the different anatomical variations of the arterial supply of the liver and stomach is of great importance in hepatobiliary and gastric surgical procedures. Therefore we believe our case will facilitate clinical aproaches related to this region.

Key words: Coeliac trunk; left gastric artery; accessory hepatic artery; posterior gastric artery.
Truncus coeliacus'un en küçük dalı olan a. gastrica sinistra, midenin curvatura minor'u boyunca ilerler. Rutin abdominal disseksiyonlar sırasında, 65 yaşındaki bir erkek kadavrada, a. gastrica sinistra'nın çoklu varyasyonlarına rastladık. A. gastrica sinistra, truncus coeliacus'un ilk dalı olarak çıkıyordu ve daha sonra iki dala ayrılıyordu. Sağ tarafa doğru giden dal, karaciğerin sol lobuna (aksesuar bir hepatik arter), fundus gastricus'a ve oesophagus'a doğru giden üç dal veriyordu. Sol tarafa doğru giden dal, iki ana truncus'a ayrılıyordu. Ön truncus, fundus gastricus'u ve midenin ön duvarını ve arka truncus, fundus gastricus'u ve midenin arka duvarını besliyordu. Dolayısıyla midenin arka duvarı a. lienalis'in dalı olan a. gastrica posterior'un yerine bu arka truncus tarafından besleniyordu. Karaciğerin ve midenin arteriyel beslenmesinin değişik anatomik varyasyonlarının bilinmesi, hepatobiliyer ve gastrik cerrahi prosedürlerde son derece önemlidir. Bu nedenle olgu sunumumuzun bu bölge ile ilgili cerrahi yaklaşımlara katkı sağlayacağı inancındayız.

Anahtar sözcükler: Truncus coeliacus; a. gastrica sinistra; aksesuar hepatik arter; a. gastrica posterior.

\section{INTRODUCTION}

The coeliac trunk is the first anterior branch of the aorta, and it has three branches; the left gastric, splenic and common hepatic arteries. The left gastric artery is the smallest branch of the coeliac axis. It ascends to the left of the midline and crosses the left crus of the diaphragm beneath the peritoneum of the upper posterior wall of the lesser sac. It runs forwards into the superior portion of the lesser omentum adjacent to the superior end of the lesser curvature. It turns anteroinferiorly to run along the lesser curvature between the two peritoneal leaves of the lesser omentum. At the highest point of its course, it gives off an oesophageal branch. Along its course in the lesser curvature, it gives off multiple branches that run onto the anterior and posterior surfaces of the stomach and anastomose with the right gastric artery in the region of the incisura angularis. ${ }^{[1]}$ 
After its origin from the coeliac axis, the common hepatic artery passes anteriorly and laterally below the epiploic foramen to the upper aspect of the superior part of the duedonum. The common hepatic artery has two terminal branches: the gastroduedonal artery and the hepatic artery proper. ${ }^{[1]}$ Nevertheless patterns of arterial blood supply to the liver are variable. Modifications of the dominant scheme, in which the liver receives its total inflow from the hepatic branch of the coeliac axis, occur in $25 \%$ to $75 \%$ of cases. ${ }^{[2]}$ Under variant patterns, the lobes may receive their blood supply from the superior mesenteric artery, left gastric artery, aorta, or other visceral branches. ${ }^{[3]}$ These vessels may be accessory, occurring in addition to the normal arterial supply, or replacements, representing the primary arterial supply to the lobe. ${ }^{[1,3]}$ Lippert and Pabst reported that they determined accessory left hepatic arteries in $11 \%$ of cases, with varying origins, more often from the left gastric artery or the coeliac trunk. ${ }^{[4]}$ Aberrant hepatic arteries can be of major surgical significance in operations of the upper intestinal tract, the gallbladder and pancreas. ${ }^{[5]}$ They can also become a technical problem for infusion therapy and transarterial chemoembolization of neoplasm in the liver. ${ }^{[6-8]}$

When a posterior gastric artery is present, it arises from the splenic artery in its middle section, posterior to the body of the stomach. ${ }^{[1]}$ The importance of the accurate delineation of the posterior gastric artery is crucial for pancreatic transplantation and gastric tumor removal. ${ }^{[9]}$

We report a 65 year old male cadaver who had not only an accessory hepatic artery but also a posterior gastric artery, originating from the left gastric artery.

\section{CASE REPORT}

During routine abdominal dissection of a 65 year old male formalin fixed cadaver, we encountered multivariations of the left gastric artery. The coeliac trunk had a classical branching pattern (It had three branches; the left gastric artery, the splenic artery, and the common hepatic artery) (Fig. 1).

The left gastric artery divided into two main branches (right and left) at the oesophagogastric junction (Fig 1). The branch which passed towards the right side gave three branches. One of these branches entered the left lobe of the liver in relationship to the fissure for ligamentum teres, from the left side of the portal vein, as an accessory hepatic artery. The second one passed towards the fundus of stomach. The third one coursed its way to the posterior of the oesophagus and it entered the oesophagus from the oesophageal hiatus (Fig. 2). The branch which passed towards the left side divided into two main trunks which ran to the anterior and posterior of the stomach. The anterior trunk supplied the fundus, the anterior wall and the lesser curvature of the stomach (Fig. 3). The posterior trunk first gave off a branch to the fundus of the stomach and then gave off multiple branches to the posterior wall of the stomach along the lesser curvature which is classically supplied by the posterior gastric artery of the splenic artery (Fig. 4).

The common hepatic artery divided into its two classical branches; the hepatic artery proper and the gastroduodenal artery. The hepatic artery proper divided into two branches; the right branch and the left branch. Before entering the liver, the left branch divided into two branches. We did not observe an anastomosis between the left branch and the accessory hepatic artery. In order to visualise the branches of the left gastric artery better, we painted some of them in red with a red pen and later took photographs of them.

\section{DISCUSSION}

The recognition of anatomic vascular abnormalities of the coeliac trunk, hepatic arteries, splenic and left gastric artery, posterior gastric artery, gastroduodenal artery and inferior phrenic arteries in modern oesophagogastric surgery is of greater importance than ever. Angiography is not routinely recommended, but it should be mandatory when complex surgeries are planned. ${ }^{[10]}$

Adachi performed large series of anatomic autopsies concerning the aberrant hepatic arteries in 1928. ${ }^{[11]}$ An angiographic study by Kostelic et al. reports the prevalence of an accessory hepatic artery as 33\%. ${ }^{[12]}$ Kosinski in 1928, Michels in 1953 and 1955, and Couinaud in 1957 described the variations of the coeliac and hepatic arterial supplies by classifying eight types. In their studies, in type II, the replaced left hepatic artery arose from the left gastric artery, while the coeliac supplied only the right and middle hepatic arteries. ${ }^{[7,13-15]}$ Afterwards Michels proposed an internationally recognized classification of these hepatic abnormalities in 1962 and this classification has served as the benchmark for all subsequent contributions in this area. ${ }^{[8]}$ Michels had classified the hepatic arterial types in 10 groups. ${ }^{[8]}$ This classification was modified by Hiatt et al. in $1994 .{ }^{[3]}$ Hiatt et al. classified the hepatic arterial types in 6 groups. Michels classified the replaced left hepatic artery from the left gastric artery as type 2 and determined the incidence of this type as $10 \%$ and also Hiatt et al. classified the replaced or accessory left hepatic artery as type 2 and determined the incidence of this type as $9.7 \% .^{[3,8]}$ Consequently the case we reported can be included in type 2 hepatic arterial type according to these researchers' classifications.

The posterior gastric artery is an important, but relatively unknown, splenic artery side branch. It may be overlooked by surgeons. It provides the blood supply to the abdominal oesophagus, fundus and spleen, and forms the superior polar splenic artery, as a terminal artery. ${ }^{[10]}$ Interestingly in our case, the posterior trunk of the left branch of the left gastric artery gave multiple branches to the posterior wall of the stomach along the lesser curvature, which is classically supplied by the posterior gastric artery of the splenic artery. 


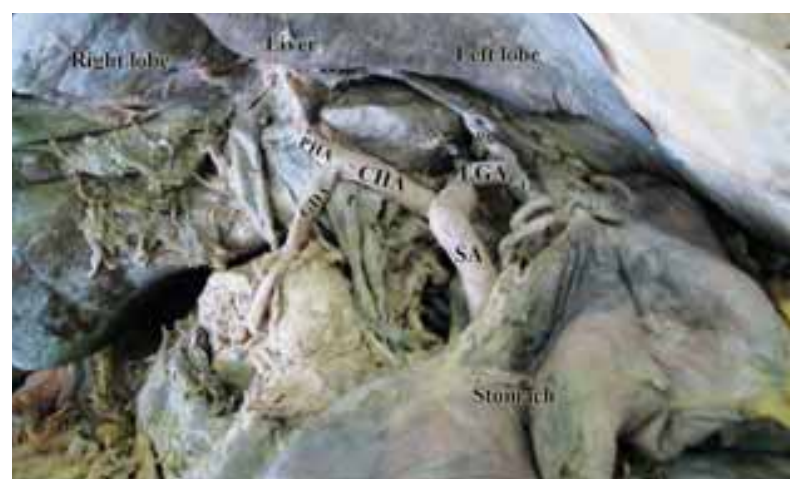

Figure 1. Anterior view of the coeliac trunk and its branches. Left and right branches of the left gastric artery, accessory hepatic artery which supplies the left lobe of the liver and branches to the stomach can be seen. CHA: common hepatic artery, SA: splenic artery, LGA: left gastric artery, Rb: right branch of LGA, Lb: left branch of LGA, PHA: proper hepatic artery, GDA: gastroduodenal artery, aHA: accessory hepatic artery.

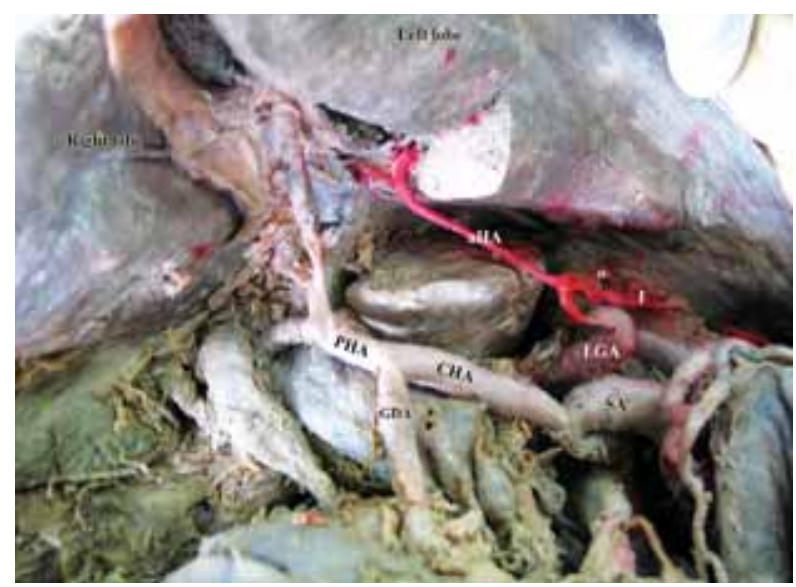

Figure 2. The right branch of the left gastric artery, its accessory hepatic branch to the left lobe of the liver and also its branches to the oesophagus and fundus of the stomach can be seen. CHA: common hepatic artery, SA: splenic artery, LGA: left gastric artery, aHA: accessory hepatic artery, o: oesophageal branches, $f$ : branches to fundus of the stomach, PHA: proper hepatic artery, GDA: gastroduodenal artery.

The anatomic variations of the coeliac trunk is a consequence of developmental impairment of the ventral splanchnic arteries. The abnormal branch ramification of the coeliac trunk is a cause of many different variation types. ${ }^{[10]}$

The existence of additional hepatic arteries has important implications for surgery, including laparoscopic cholecystectomy, common bile duct explorations (incisions or excisions), Whipples' operation, radical hepatic surgery, liver transplantation, especially split liver transplantation, and for endovascular procedures in the liver, such as chemoembolization in which surgical ligation or coil occlusion of the gastroduodenal artery is recommended prior to surgical placement of an infusion pump for continuous direct intrahepatic arterial

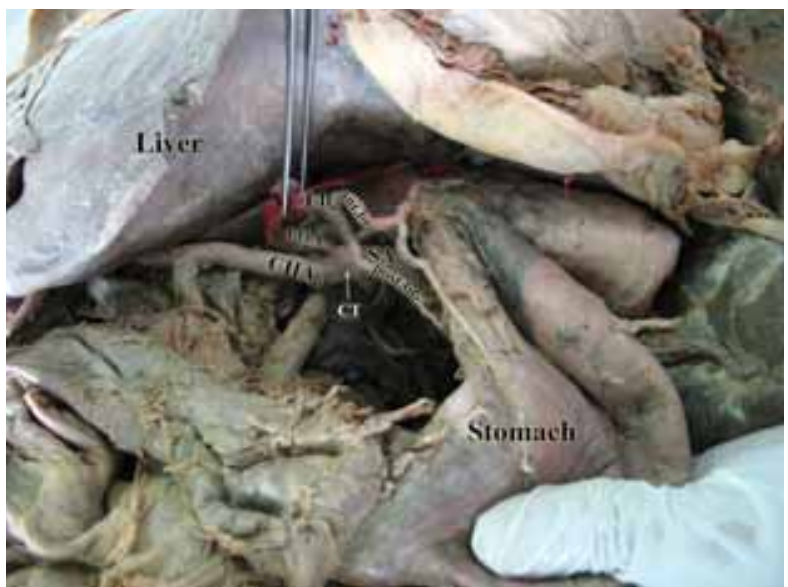

Figure 3. The left branch of the left gastric artery, its branches to the anterior and posterior surfaces of the stomach and distribution of the anterior branch can be seen. CT: coeliac trunk, SA: splenic artery, CHA: common hepatic artery, LGA: left gastric artery, Lb: left branch of $L G A$, ant.br:: anterior branch of the left branch of LGA, post.br.: posterior branch of the left branch of LGA.

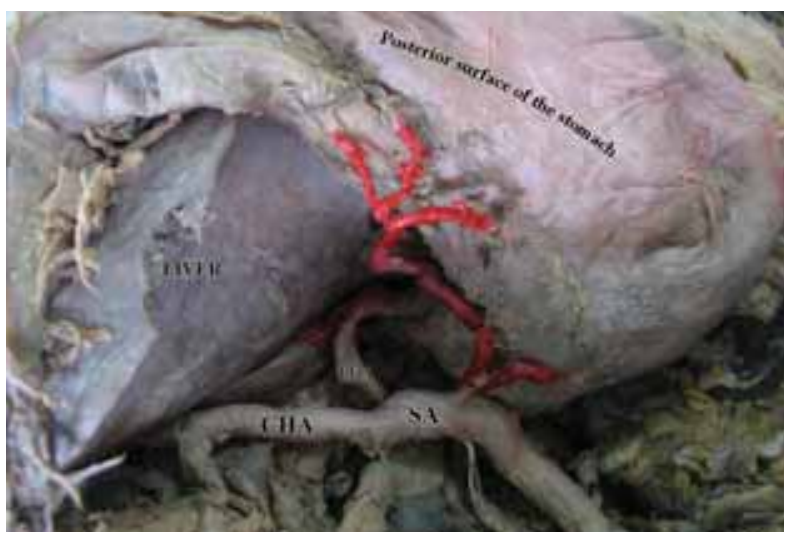

Figure 4. The distrubution of the posterior branch of the left branch of $L G A$ to the fundus and posterior surface of the stomach can be seen. SA: splenic artery, CHA: common hepatic artery, LGA: left gastric artery, post.br.: posterior branch of the left branch of $L G A$.

chemotherapy of liver neoplasms. ${ }^{[16,17]}$ During minimally invasive or complicated hepatobiliary surgery, an understanding of arterial variants in the lesser omentum is necessary if serious problems are to be avoided. ${ }^{[18]}$

Precise knowledge about hepatic arterial anatomy is not important for hepatobilliar surgeons alone. ${ }^{[10]}$ Variations of the left gastric artery have great importance during perivascular lymph node dissection. If an accessory hepatic artery originates from the left gastric artery, it means that up to $20 \%$ of accessory left hepatic arteries supply more than two liver segments. The left gastric artery should be preserved during lymphadenectomy because a left hepatic artery of the accessory type frequently persists in about $19-26 \%$ of gastric cancer patients. ${ }^{[10]}$ Moreover, if the hepatic artery proper shows 
reduction of diameter, and the left hepatic artery has a diameter greater than 2-3 mm, suppression of blood supply provided by an accessory artery, may have clinical impact, which is sometimes lethal. ${ }^{[19,20]}$

The importance of accurate delineation of the posterior gastric artery is essential for pancreatic transplantation and gastric tumor removal. In addition, knowledge of variation in this vessel's origin could be useful in transcatheter arterial embolization for the treatment of chronic bleeding from gastric ulcers. Moreover, ligation of this vessel during partial gastrectomy, pancreaticoduodenectomy and parietal cell vagotomy may result in gastric wall necrosis and gastric stump leak. ${ }^{[9]}$

Our case, who had not only an accessory hepatic artery but also a posterior gastric artery originating from the left gastric artery, sets an interesting example for the complex anatomy of the coeliac trunk. Thus, we believe that our case will provide a contribution to the literature, as knowledge of variations concerning the coeliac trunk has major clinical importance for surgical procedures regarding the upper abdomen.

\section{Conflict of Interest}

No conflict of interest declared by the authors.

\section{REFERENCES}

1. Adachi B. Das Arteriensystem der Japaner, Band II. Maruzen, Kyoto. 1928;16-64.

2. Bergman R, Thompson SA, AWW AK, Saadeh FA. Compendium of human anatomic variation: text, atlas, and world literature. Urban \& Schwarzenberg, Baltimore Munich; 1988;77-9.

3. Chevallier JM, Hannoun L. Anatomical bases for liver transplantation. Surg Radio Anat 1991;13:7-16.

4. Couinaud C. L'artère hépatique In: Le foie: Ëtudes anatomiques et chirurgicales. Paris: Masson et Cie; 1957;146-86.

5. Elias D, Lasser P, Rougier P. A simplified surgical technical procedure for intra-arterial chemotherapy in secondary liver cancer. Eur J Surg Oncol 1987;13:441-8.
6. Friesen S R. The significance of the anomalous origin of the left hepatic artery from the left gastric artery in operations upon the stomach and esophagus. Am Surg 1957;23:1103-8.

7. Hiatt JR, Gabby J, Busuttil RW. Surgical anatomy of the hepatic arteries in 1000 cases. Ann Surg 1994;220:50-2.

8. Kosinski Ch. Quelques observations sur les rameaux du tronc coelique et des artères mésentériques chez l'homme. C R Assoc Anat 1928;23:241-60.

9. Kostelic JK, Piper JB, Leef JA, Lu CT, Rosenblum JD, Hackworth C, et al. Angiographic selection criteria for living-related liver transplant donors. Am J Roentgenol 1996;166:1103-8

10. Lippert H, Pabst R. Arterial variations in man: classification and frequency. JF Bergmann Verlag, Munchen;1985;34-35: 71-3.

11. Loukas M, Wartmann CT, Louis RG jr, Tubbs RS, Ona M, Curry B, et al. The clinical anatomy of the posterior gastric artery revisited. Surg Radiol Anat 2007;29:361-6.

12. Lurie A S. The significance of the variant left accessory hepatic artery in surgery for proximal gastric cancer. Arch Surg 1987;122:725-8.

13. Mcnulty JG. Total anomalous arterial supply to the liver and gallbladder from the gastroduodenal artery: a case report; Surg Radiol Anat 2000;22:123-4.

14. Michels NA. Variational anatomy of the hepatic, cystic, and retroduodenal arteries. Arch Surg 1953;66:20-34.

15. Michels NA. Blood supply and anatomy of the upper abdominal organs with a descriptive atlas. JB Lippincott Company, Philadelphia; 1955;139-65.

16. Michels NA. Newer anatomy of the liver and its variant blood supply and collateral circulation. Am J Surg 1966;112:337-47.

17. Nelson TM, Pollak R, Jonasson O, Abcarian H. Anatomic variants of the coeliac, superior mesenteric and inferior phrenic arteries and their clinical relevance. Clin Anat 1988;1:75-91.

18. Randjelovic DT, Filipovic RB, Bilanovic LD, Stanisavljevic $\mathrm{SN}$. Perigastric vascular abnormalities and the impact on esophagogastrectomy. Dis Esophagus. 2007;20:390-8.

19. Standring S. Gray's Anatomy. Thirtyninth edition. Churchill Livingstone, Spain 2005;1118, 1146, 1218.

20. Todo S, Makowka L, Tzakis AG, Marsh JW Jr, Karrer FM, Armany M, et al. Hepatic artery in liver transplantation. Transplant Proc 1987;19:2406-11. 